\author{
Horolma Pamjav ${ }^{1}$ \\ Dimitra Triga ${ }^{1}$ \\ Zsuzsanna Buzás ${ }^{2}$ \\ Tibor Vellai ${ }^{1}$ \\ Attila Lucskai ${ }^{3}$ \\ Byron Adams ${ }^{4}$ \\ Alexander P. Reid ${ }^{5}$ \\ Ann Burnell ${ }^{6}$ \\ Christine Griffin ${ }^{6}$ \\ Itamar Glazer ${ }^{7}$ \\ Michael G. Klein ${ }^{8}$ \\ András Fodor ${ }^{1}$ \\ ${ }^{1}$ Department of Genetics, \\ Eötvös University, \\ Budapest, Hungary \\ ${ }^{2}$ Agricultural Biotechnology \\ Center, Gödöllõ, Hungary \\ ${ }^{3}$ Institute of Plant Protection, \\ Georgikon Agricultural \\ Faculty, Pannon University \\ of Agricultural Sciences, \\ Keszthely, Hungary \\ ${ }^{4}$ Department of Plant \\ Pathology, University of \\ Nebraska \\ Lincoln, NE, USA \\ ${ }^{5} \mathrm{CAB}$ International, \\ International Institute of \\ Parasitology, \\ St. Albans, Herts, UK \\ ${ }^{6}$ Department of Biology, \\ National University of \\ Ireland, Maynooth, Ireland \\ ${ }^{7}$ Department of Nematology, \\ A.R.O. The Volcani Center, \\ Bet Dagan, Israel \\ ${ }^{8}$ USDA, Agricultural \\ Research Service, \\ Wooster, $\mathrm{OH}, \mathrm{USA}$
}

\section{Novel application of PhastSystem polyacrylamide gel electrophoresis using restriction fragment length polymorphism - internal transcribed spacer patterns of individuals for molecular identification of entomopathogenic nematodes}

\begin{abstract}
A relatively rapid and economic way of identifying and assigning nematodes to taxons, which had already been determined either by comparative sequence analysis of nuclear rDNA internal transcribed spacer (ITS) region or by other methods of molecular or conventional taxonomy, is provided. Molecular identification of entomopathogenic nematodes (EPN) can be upgraded by basing it on PhastSystem polyacrylamide gel electrophoresis (PAGE) analysis of restriction fragment length polymorphism (RFLP) patterns of polymerase chain reaction (PCR)-amplified DNA derived from single nematodes of Steinernema or Heterorhabditis spp. Although analysis from single worms has previously been made on agarose gel, the resolution on PhastSystem PAGE gel is much higher. The DNA sequences selected for analysis were those constituting the internal transcribed spacer region between the 18S and 26S rDNA genes within the rRNA operon. RFLP analysis was carried out by gel electrophoresis on the PhastSystem (Pharmacia) as detailed elsewhere (Triga et al., Electrophoresis 1999, 20, 12721277. The downscaling from conventional agarose to PhastSystem gels resulted in pattern of DNA fragments differing from those obtained with agarose gel electrophoresis under conventional conditions by increasing the number of detected fragments. The approach supported previous species identifications and was able to identify several unclassified isolates, such as those from Hungary and Ireland, and provides a method for identification of previously unclassified strains. We confirmed that Heterorhabditis "Irish Type", represented by two strains of different geographical origin, comprise a species different from $H$. megidis. We also confirmed that strain IS5 belongs to the species $H$. indicus rather than to $H$. bacteriophora, as had been suggested previously.
\end{abstract}

Keywords: Molecular diagnostics / Identification / Entomopathogenic / Nematode / Heterorhabditis / Steinernema

EL 3384

\section{Introduction}

Entomopathogenic nematodes (EPN) [1] belonging to the genera Heterorhabditis (the prokaryotic symbiont of which is Photorhabdus luminescens [2-4]) and Steinernema (the prokaryotic symbiont of which is Xenorhabdus spp., [2-4]) possess great potential as bioinsecticides and are attractive from a biological and commercial viewpoint. Phylogenetic analysis of Phylum Nematoda [5], based

Correspondence: Dr. Zsuzsanna Buzás, Agricultural Biotechnology Center, H-2101 Gödöllõ, POB 411, Hungary

E-mail: buzas@ @ubi.abc.hu

Fax: +36-28-430338

Abbreviations: EPN, entomopathogenic nematodes; ITS, internal transcribed spacer; NWE, North Western European upon 18S rDNA sequence homology, indicates that steinernematids and heterorhabditids are phylogenetically relatively far from each other within Rhabditida [6]. On the basis of the 18S rDNA sequences, genera could be well separated within Phylum Nematoda [5]. EPN strains can be found all over the world [8]. The internal transcribed spacer (ITS) region of the nuclear ribosomal DNA [7, 9] appears to be a reliable marker for identifying species within each EPN genera.

Nematode taxonomy has been mainly based upon morphological and morphometric characters. Since the steinernematids are amphimictic, cross-breeding between virgin females and males of good fertility is sufficient to establish true biological species, and allow identification. For the Steinernema, an international team led by W. Hominick presented a revised taxonomy based on unam- 
biguously standardized morphological and molecular identification criteria. This revision had consensus since the morphological/morphometric and molecular characters fitted perfectly and the following species are recognized: S. kraussei [14], S. glaseri [15], S. feltiae [16], S. affinis [1], S. carpocapsae [17], S. anomali [18], S. intermedium [19], S. rarum [20, 21], S. kushidai [22, 23], S. scapterisci [24], as well as S. riobravum, S. bicornutum, S. ritteri, S. serratum, S. cubanum, S. caudatum, and $S$. longicaudatum [25].

The diagnosis of Heterorhabditis needs a more sophisticated molecular tool kit because of the more complicated situation. Although only one genus (Heterorhabditis) belongs to the family Heterorhabditidae [26], each species exists in alternating automictic and amphimictic cycles [27], and the researcher needs some practice to be able to distinguish between self progeny and cross progeny. That is probably the main reason why the crossbreeding technique [28] has rarely been used for identifying biological species in this genus. Instead, new species have been determined by morphology, electrophoretic and electrofocusing analyses of polypeptides [29, 30] and DNA fingerprinting $[1,10,33,34]$. The first species in the taxon was $H$. bacteriophora [31]. More and more Heterorhabditis isolates were identified morphologically and morphometrically on the basis of genetic, cytogenetic and protein polymorphism, with the ultimate aim of diagnosing phenetic or biological species [8, 12, 13, 32-42]. However, no evolutionary or phylogenetic species concept has been considered until recently $[12,13]$. To avoid confusion, we refer to the literature describing Heterorhabditis strains and aligning them to different species [27, 3133, 43-45].

Accumulated evidence $[10,11,34,35]$ suggests that DNA sequences of the internally transcribed region of the rRNA tandem repeat (ITS) could provide the requisite heritable characteristic for a thorough phylogenetic analysis. The advantages and taxonomic suitability of this marker include the potential for PCR amplification and sequencing by universal primers, forced uniformity of paralogues via rapid concerted evolution, variation due primarily to point mutations, apparent independence of variable sites, and phylogenetic information appropriate for species level investigations [12]. In a comprehensive study by Adams et al. [13], phylogenetic relationships among nine representative strains of Heterorhabditis, each considered as distinct species, were determined by using DNA sequences of the ITS1 region of the ribosomal tandem repeat unit. The authors demonstrated that this region performs better at resolving relationships among closely related sister taxa than among inclusive clades [13].
The studies based upon comparison of ITS as well as mitochondrial DNA sequences made it possible to separate species of "phylogenetic" H. bacteriophora, H. megidis, $H$. argentinensis, $H$. indicus, $H$. zealandica, and $H$. marelatus. The latter was represented by two strains of different geographical origin, $H$. hepialius (Bodega Bay isolate) and $H$. marelatus (Oregon strains). Though initially thought to be separate species, they were later synonymized [42]. The $H$. bacteriophora phylogenetic species includes several "biological species" [12, 27]. These studies provide a frame within which unclassifed strains could be assigned, on condition that proper and accurate tools of molecular identification were available. In our study we focused on strains not involved in the previous study [13] but that should be unambiguously assigned, such as IS5 [46] and EU349/HIT (Griffin et al., submitted; [8]).

First we demonstrate that the new method for molecular identification of EPN [48] provides comparable results to those obtained by comparative sequence analyses [13]. The study presented here provides a new technique, the PhastSystem PAGE, as a contribution to the molecular tool kit of EPN taxonomy. We analyzed several digestion patterns of PCR-amplified ITS sequences from different Steinernema and Heterorhabditis species and strains. We show that the patterns obtained by the new technique are identical to the already published patterns [25] obtained by agarose electrophoresis for the genus Steinernema. The new method provides better resolution in the range of $100 \mathrm{bp}$ DNA length.

\section{Materials and methods}

\subsection{EPN strains}

The EPN strains used in this study as well as their source are listed in Table 1.

\subsection{Molecular techniques}

The techniques consisted of extraction of DNA, PCR amplification of the ITS region, restriction endonuclease digestion of PCR products, and gel electrophoresis of the DNA fragments on the PhastSystem (Pharmacia, Uppsala, Sweden). DNA was extracted after lysis of individual EPN, using standard proteinase $\mathrm{K}$ digestion and DNA purification methods [8]. PCR amplification of the ITS region was carried out as described previously [49]. For the Steinernema species, the two primers were $18 \mathrm{~S}$ (forward) and 26S (reverse) [9]. For the Heterorhabditis species, the primers were AB 28 (18S forward) and TW 81 (26S reverse) (John Curran, personal communication). PCR products were identified by electrophoresis on $1 \%$ agarose gel in TBE buffer. For the restriction endonuclease digestion of PCR products Alul, Ddel, Hin-fl and Rsal enzymes were used. Gel electrophoresis of the DNA 
Table 1. EPN strains and origin

\begin{tabular}{|c|c|c|c|c|}
\hline Genus & Species & Strain & Notes & Origin \\
\hline Steinernema & carpocapsae & Mexicana & & James E. Lindegreen, 1986 \\
\hline Steinernema & intermedium & $224-35-11$ & BIOSYS & Lonne Gerritsen, 1994 \\
\hline Steinernema & anomali & Azores & & Nelson Simoes, 1996 \\
\hline Steinernema & scapterisci & Scapterisci & & Harry Kaya, 1997 \\
\hline Steinernema & glaseri & NC 513 & & Lonne Gerritsen, 1994 \\
\hline Steinernema & feltiae & IS6 & & Itamar Glazer, 1995 \\
\hline Steinernema & oh-sp & KMD 15 & Unpublished & $\begin{array}{l}\text { Attila Lucskai and Michael } \\
\text { G. Klein, } 1997\end{array}$ \\
\hline Heterorhabditis & bacteriophora & Heliothidis & & Lonne Gerritsen, 1995 \\
\hline Heterorhabditis & $\begin{array}{l}\text { argentinen- } \\
\text { sis }\end{array}$ & $\begin{array}{l}\text { Argentinen- } \\
\text { sis }\end{array}$ & $\begin{array}{l}\text { or bacterio- } \\
\text { phora }\end{array}$ & Byron Adams, 1997 \\
\hline Heterorhabditis & megidis & HE87.3 & NWE & Lonne Gerritsen, 1994 \\
\hline Heterorhabditis & marelatus & Hepialius & & Byron Adams, 1997 \\
\hline Heterorhabditis & zealandica & $\mathrm{NZH3}$ & & Ann Burnell, 1997 \\
\hline Heterorhabditis & indicus & LN2 & Coimbatore & Ann Burnell, 1997 \\
\hline Heterorhabditis & indicus & IS5 & $\begin{array}{l}\text { or bacterio- } \\
\text { phora }\end{array}$ & Itamar Glazer, 1994 \\
\hline Heterorhabditis & Irish Type & K122 & $\begin{array}{l}\text { or megidis } \\
\text { from Ireland }\end{array}$ & Christine Griffin, 1994 \\
\hline Heterorhabditis & $\begin{array}{l}\text { Irish Type } \\
\text { from Hun- } \\
\text { gary (HIT) }\end{array}$ & $\begin{array}{l}\text { EU349/HIT } \\
\text { isolated by } \\
\text { C. Griffin, } \\
\text { M. Downes }\end{array}$ & $\begin{array}{l}\text { or megidis } \\
\text { from } \\
\text { Hungary }\end{array}$ & Christine Griffin, 1994, 95 \\
\hline
\end{tabular}

IS5 [46] was believed to be $H$. bacteriophora, since it can successfully be crossed with $H$. bacteriophora [50] strain HP88 [47].

fragments was carried out on the PhastSystem at $15^{\circ} \mathrm{C}$, using stacking gels of $5 \% \mathrm{~T}, 3 \% \mathrm{C}$ (Bis) and resolving gels of $7.5 \% \mathrm{~T}, 5 \% \mathrm{C}$ (Bis). The stacking and resolving gel buffer was $0.112 \mathrm{~m} \mathrm{Na}$ acetate, $0.112 \mathrm{M}$ Tris, $\mathrm{pH} 6.4$, and the catholyte and anolyte were $0.2 \mathrm{~m}$ tricine, $0.2 \mathrm{M}$ Tris, $0.55 \%$ SDS, pH 8.1, contained in $2.8 \%$ IsoGel agarose strips $[48,49]$. Data processing was carried out as described elsewhere [49].

\section{Results}

\subsection{Identity between Heterorhabditis "Irish Type" strains K122 and EU349/HIT}

The identical nature of strain $\mathrm{K} 122$ isolated in Ireland, and EU349/HIT isolated in Hungary was demonstrated by the indistinguishable RFLP patterns in PhastSystem gels of digests prepared with four different restriction enzymes (Fig. 1).

3.2 Distinction between phylogenetic species H. megidis and Heterorhabditis "Irish Type" (comparison of "Irish Type" strains K122 to a North Western European (NWE) strain of H. megidis, HE87.3)

A comparison of four RFLP patterns derived from different restriction enzymes of strain $\mathrm{K} 122$ and $H$. megidis
NWE demonstrates that these two strains are not identical (Fig. 2).

\subsection{Identity of Heterorhabditis species $\boldsymbol{H}$. argentinensis and $\boldsymbol{H}$. bacteriophora}

The RFLP patterns obtained for four restriction digests of strains Argentinensis and Heliothidis are indistinguishable, demonstrating their identity (Fig. 3).

\subsection{Assignment of Israeli strain IS5 to species H. indicus}

The assignment of strain IS5 to either $H$. indicus or $H$. bacteriophora was resolved in favor of the former, based on the identical RFLP patterns of IS5 and LN2 (Coimbatore) strain of $H$. indicus and the lack of similarity between IS5 and $H$. bacteriophora (Heliothidis) gel patterns (Fig. 4).

\subsection{Distinction of $\boldsymbol{H}$. zealandica from any other Heterorhabditis strain}

The RFLP pattern of $H$. zealandica (NZH3) differs from that of any of the other strains depicted in Fig. 5. The patterns of Fig. 5 derive from digestion with restriction 


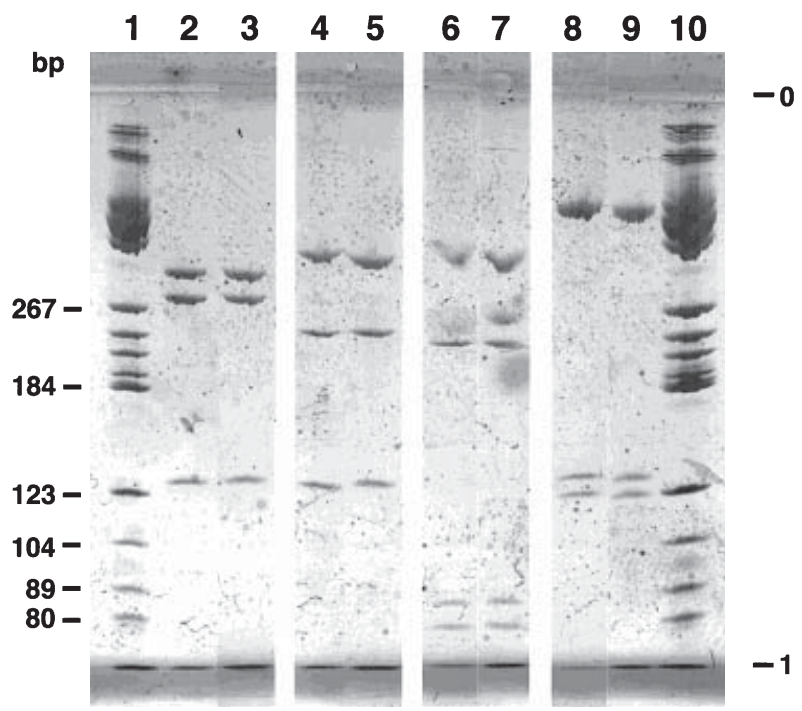

Figure 1. Identity between Heterorhabditis "Irish Type" strain K122 and Hungarian "Irish Type" EU349/HIT. RFLP analysis on the PhastSystem at $15^{\circ} \mathrm{C}$, using $7.5 \% \mathrm{~T}, 5 \% \mathrm{C}$ (Bis) resolving gel in $0.112 \mathrm{~m}$ Tris/acetate buffer, $\mathrm{pH} 6.4$. Digests of restriction endonucleases Alul, Ddel, Hinfl and $R s a l$ are depicted in this order in gel lanes (2), (4), (6), and (8) in the case of strain $\mathrm{K} 122$, and restriction fragments of strain EU349/HIT are shown in (3), (5), (7), and (9). DNA fragments of the size standard ladder migrated as shown in (1) and (10).

enzyme Hinfl. The same distinction of the $H$. zealandica pattern from all the others under consideration was also demonstrated for three other restriction digests (data not shown).

\subsection{KMD 15, a new Steinernema isolate representing a novel species}

An isolate from Ohio being described as a new species (Lucskai and Klein, in preparation) exhibits RFLP patterns in three restriction digests which are different from those of all other strains under consideration. This distinction is exemplified in Fig. 6.

\section{Discussion}

The following Heterorhabditis species were recognized by molecular identification: $H$. bacteriophora, $H$. indicus, $H$. marelatus, $H$. megidis, $H$. zealandica, and $H$. argentinensis [13]. Four pairs of sister species were finally determined in the genus, namely: $H$. megidis and Heterorhabditis "Irish Type"; H. Zealandica; $H$. hepialius and $H$. marelatus; $H$. bacteriophora and $H$. argentinensis; and $H$. indicus and $H$. hawaiiensis. On the basis of molecular analysis, some of these sister taxa may be conspecific, namely, $H$. hepialius and $H$. marelata; $H$. indicus and $H$. hawaiiensis; $H$. bacteriophora and $H$. argentinensis

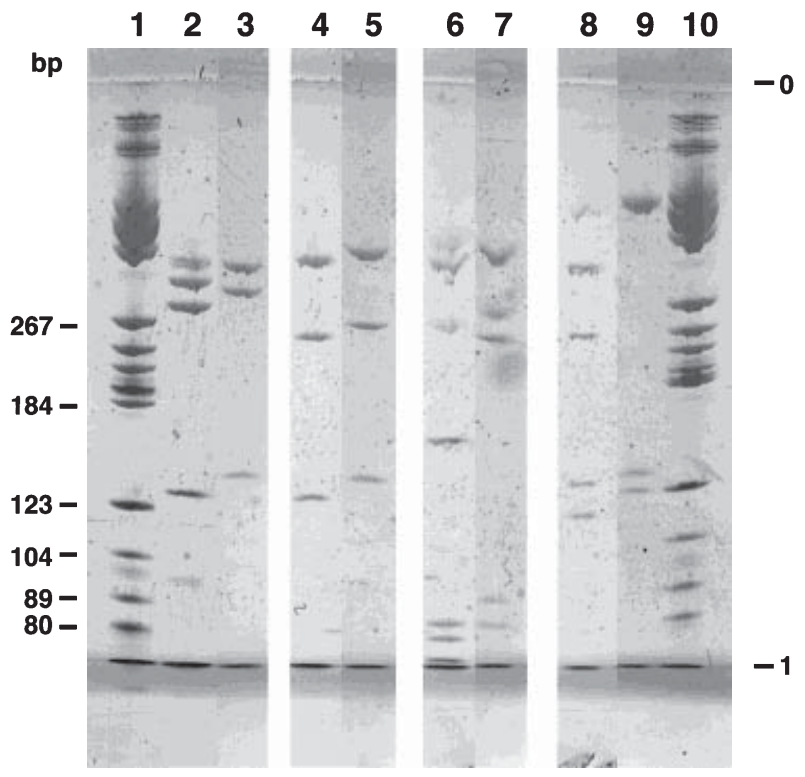

Figure 2. Comparison of Heterorhabditis "Irish Type" strain K122 to an NWE strain of $H$. megidis HE87.3. RFLP analysis on the PhastSystem using the same conditions as in Fig. 1. Digests of restriction endonucleases Alul, Ddel, Hinfl and Rsal are depicted in this order in gel lanes (2), (4), (6), and (8) in the case of strain HE 87.3, and restriction fragments of strain K122 are shown in (3), (5), (7), and (9). Lanes (1) and (10) depict the patterns of DNA size standards.

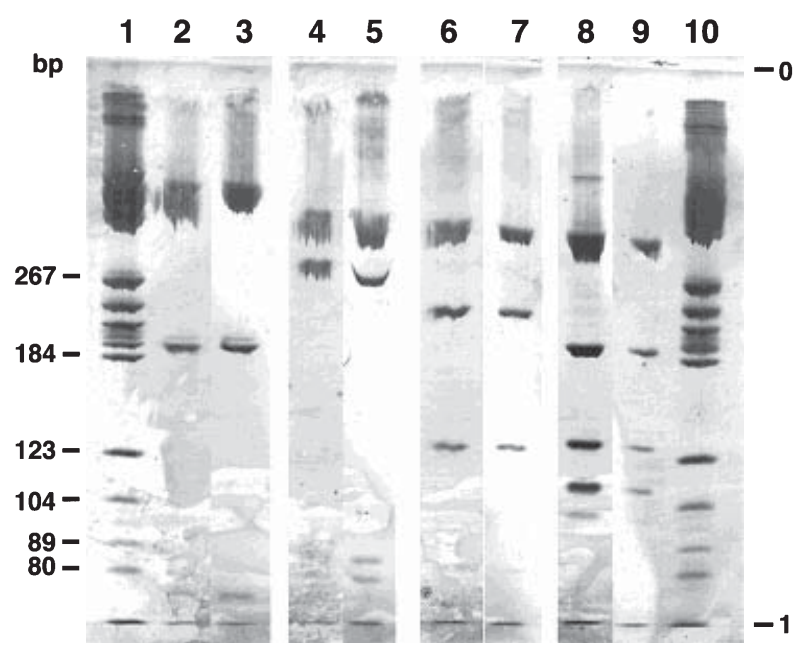

Figure 3. Identity between Heterorhabditis strains $H$. argentinensis and $H$. bacteriophora. RFLP analysis on the PhastSystem using the same conditions as in Fig. 1. Order of the restriction endonucleases: Rsal, Hinfl, Ddel and Alul. Digests of PCR product of strain $\mathrm{H}$. argentinensis are shown in gel lanes (2), (4), (6), and (8); lanes (3), (5), (7), and (9) depict the restriction fragments of strain $H$. bacteriophora; (1) and (10), patterns of DNA size standards. 


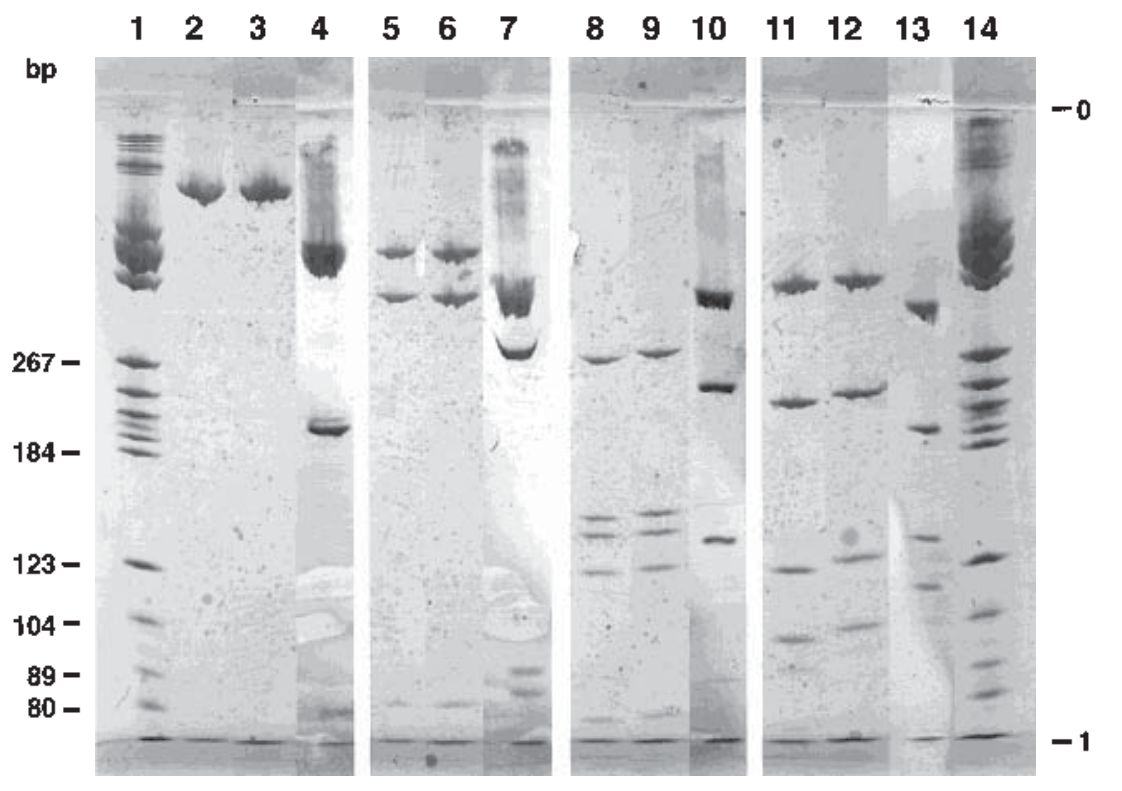

Figure 4. Assignment of Israeli strain IS5 to species $H$. indicus. RFLP analysis on the PhastSystem using the same conditions as in Fig. 1. Order of the restriction endonucleases: Rsal, Hinfl, Ddel and Alul. Lanes (3), (6), (9), and (12), restriction fragments of PCR product of IS5 strain of $\mathrm{H}$. indicus; (2), (5), (8), and (11); restriction fragments of PCR product of LN2 strain of $H$. indicus; (3), (7), (10), and (13); restriction fragments of PCR product of Heliothidis strain of $H$. bacteriophora; (1) and (14), patterns of DNA size standards.
[13]. In fact, phylogenetic relationships between these pairs were also resolved but are less well supported. A high degree of sequence identity and lack of apomorphic characters suggest that sister species pairs within three distinct lineages may be mutually conspecific [13].

To date, all $H$. bacteriophora strains examined by us (data not presented) exhibit identical patterns to that of strain Heliothidis (Fig. 4). None of the strains seemed different from the EPN $H$. argentinensis. Thus our data provide more evidence for the conclusion of conspecificity of different strains assigned to $H$. bacteriophora and $H$. argentinensis, as suggested [13]. Heterorhabditis strains belonging to the so-called NWE group were considered as $H$. megidis when compared to the original $\mathrm{OHI}$ $H$. megidis strain [43]. Natural bacterial symbionts of $\mathrm{OHI}$ and NWE strains definitely belong to different subclusters (IV and II, respectively) of Photorhabdus luminescens [4] but they can grow on and are capable of utilizing each others' symbionts (Böszörményi et al., in preparation).

It was reported that Heterorabditis strains isolated in Ireland and classified as Heterorhabditis "Irish Type" (represented by strains such as K122 or M145 [10, 28, 35, 45]) differ from both $H$. bacteriophora and $H$. megidis. The most convincing evidence of the phylogenetic separation of the Irish $\mathrm{K} 122$ and $H$. megidis $\mathrm{OHI}$ strain was provided by Adams et al. (Fig. 3 in [13]), reporting differences of the ITS sequences of $\mathrm{OHI}$ and $\mathrm{K} 122$. Our results presented in Fig. 2 demonstrate that $\mathrm{K} 122$ is also completely different from the $H$. megidis NWE strain HE 87.3. On the other hand, an "Irish Type" Heterorhabditis strain (EU349/HIT) isolated in Hungary (Griffin et al., submitted; [8]), shows a gel pattern identical to K122, but different from HE 87.3.
Our data (presented in Fig. 1) unambiguously indicate that K122 and EU349/HIT are identical. Using polyacrylamide gel electrophoresis in the PhastSystem, no differences between the two "Irish Type" strains, K122 and EU349/HIT, could be found and their patterns were similar to those of strain M145 "Irish Type" in Reid's data (Fig. 5), but differed characteristically from any megidis species, as well as from the $H$. marelatus (Hepialius) pattern (Fig. 2). Our data confirm that Heterorhabditis "Irish Type" strains comprise a distinct phylogenetic species [13] and contradict the hypothesis of conspecificity of $H$. megidis and "Irish Type" Heterorhabditis. This would support previous work from the Maynooth group (Griffin et al., submitted; [8, 10, 28, $30,35])$. Definitely, there are similar and dissimilar digestion patterns of $H$. megidis $(\mathrm{OHI}+\mathrm{NWE})$ and Heterorhabditis "Irish Type" isolates, depending upon the enzymes used. Joyce et al. [30] could also distinguish between them using protein IEF. On the other hand, in the rDNS ITS region, 35 substitutions were found between Heterorhabditis "Irish Type" $\mathrm{K} 122$ and $\mathrm{H}$. megidis $\mathrm{OHI}$, in contrast with one substitution between $H$. marelatus and $H$. hepialius; two substitutions between $H$. indicus and $H$. hawaiiensis [35] and one substitution between $H$. bacteriophora and $H$. argentinensis [13].

Our results on IS5, supporting Reid's previous (unpublished) findings, suggest that it is identical to $H$. indicus (Fig. 4). Due to cross-breeding data [50], IS5 was previously assigned to $H$. bacteriophora. In fact, the problem of the contradiction of the biological and phylogenetic species concept has not yet been solved: IS5 and HP88 strains belonging to different phylogenetic species could be crossed successfully [46, 47, 50]; in spite of that, neither $H$. bacteriophora nor $H$. megidis can utilize or retain 


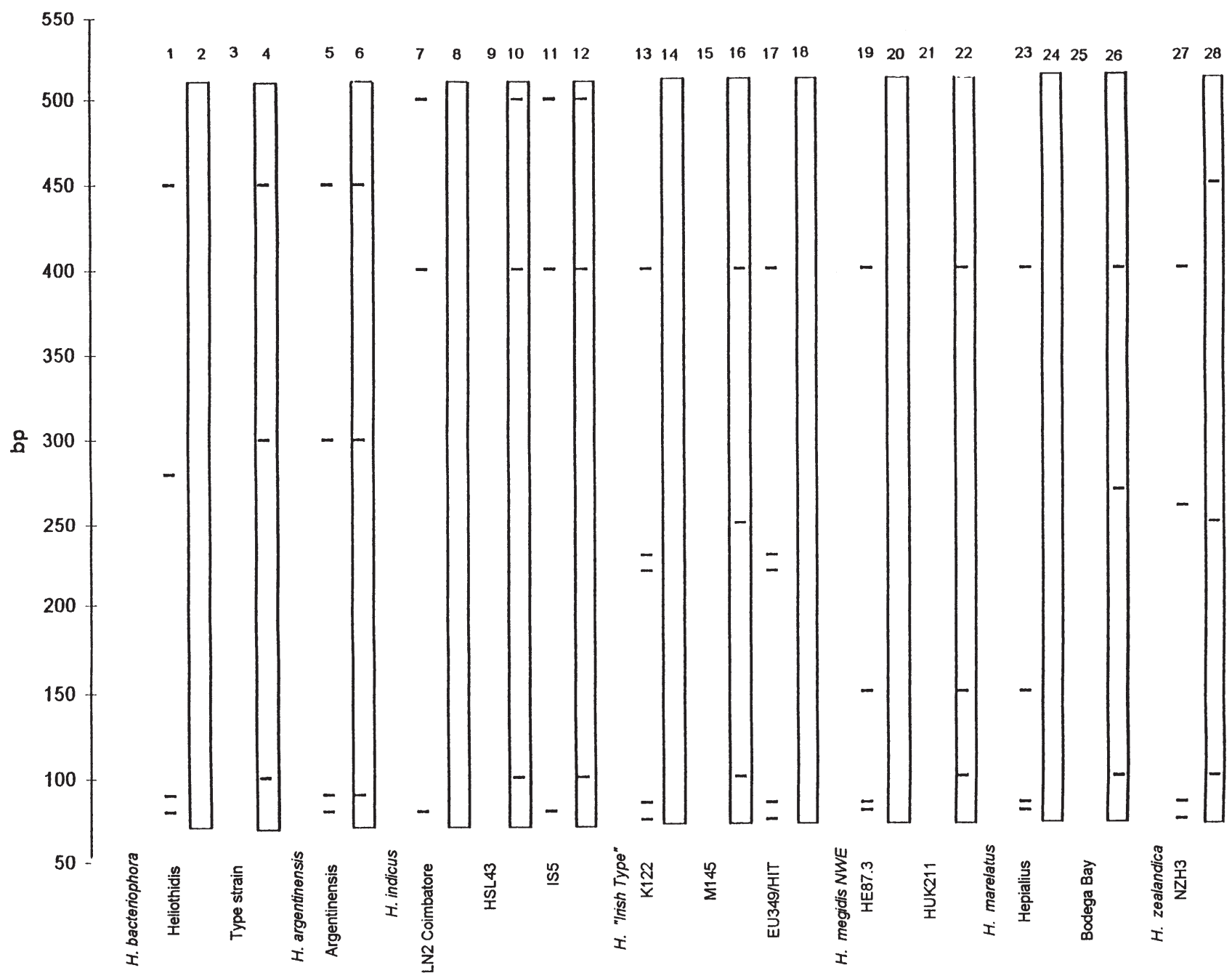

Figure 5. Improved resolution of the PhastSystem RFLP patterns compared to agarose gel electrophoresis patterns of DNA from individuals of strains representing different Heterorhabditis species. RFLP analysis on the PhastSystem using the same conditions as in Fig. 1. Gel electrophoresis patterns on agarose gels derived from Reid et al. [25]. The patterns derive from digestion with restriction endonuclease Hinfl. The patterns of the NZH3 strain, lanes (27) and (28), of $H$. zealandica are distinct from any other Heterorhabditis strain. The $28 \mathrm{gel}$ lanes represent RFLP patterns on acrylamide (odd numbers) and agarose gels (even numbers, boxed lanes). There is no data in the empty lanes.

the bacterial symbiont of IS5 as its own (Böszörményi et al., in preparation). IS5 can grow only on a few $\mathrm{H}$. bacteriophora symbionts, such as HP88. H. zealandica differs from any other strain examined (Fig. 5), supporting its status as a separate species, in agreement with [13]. Two other strains $(H$. hepialius, $H$. marelatus) $[37,40,41]$ were reported to belong to the same species, indistinguishable from the others. This was also proved in a previous molecular study [13]. Both H. marelatus and the "Irish Type" strains seem to be closer to $H$. megidis than to either $H$. bacteriophora or $H$. zealandica or $H$. indicus, on the basis of satellite sequence homology (unpublished data).

Steinernematids present a rather clear picture. Each species examined, including the new KMD 15 strain from
Ohio, provides a characteristic pattern (Fig. 6). Comparing the patterns of different steinernematids obtained from restriction digests of $A / u l, D d e l$, and Hinfl, to those previously determined [25] on agarose gels, it was found that the two methods provide the same identification. Patterns were similar except that resolution in the lower molecular weight region of the gel (100 bp) was superior in the PhastSystem gels. In fact, some of the single bands seen on the agarose gels proved to the double the size of small molecular species. For instance, when one compares $S$. intermedium patterns obtained from an Alul digest (Fig. 6) with the corresponding agarose gel pattern, it appears that the thick band on the agarose gel (200 bp) can be separated into distinct bands of 180 and $200 \mathrm{bp}$. Other bands appear similar. 


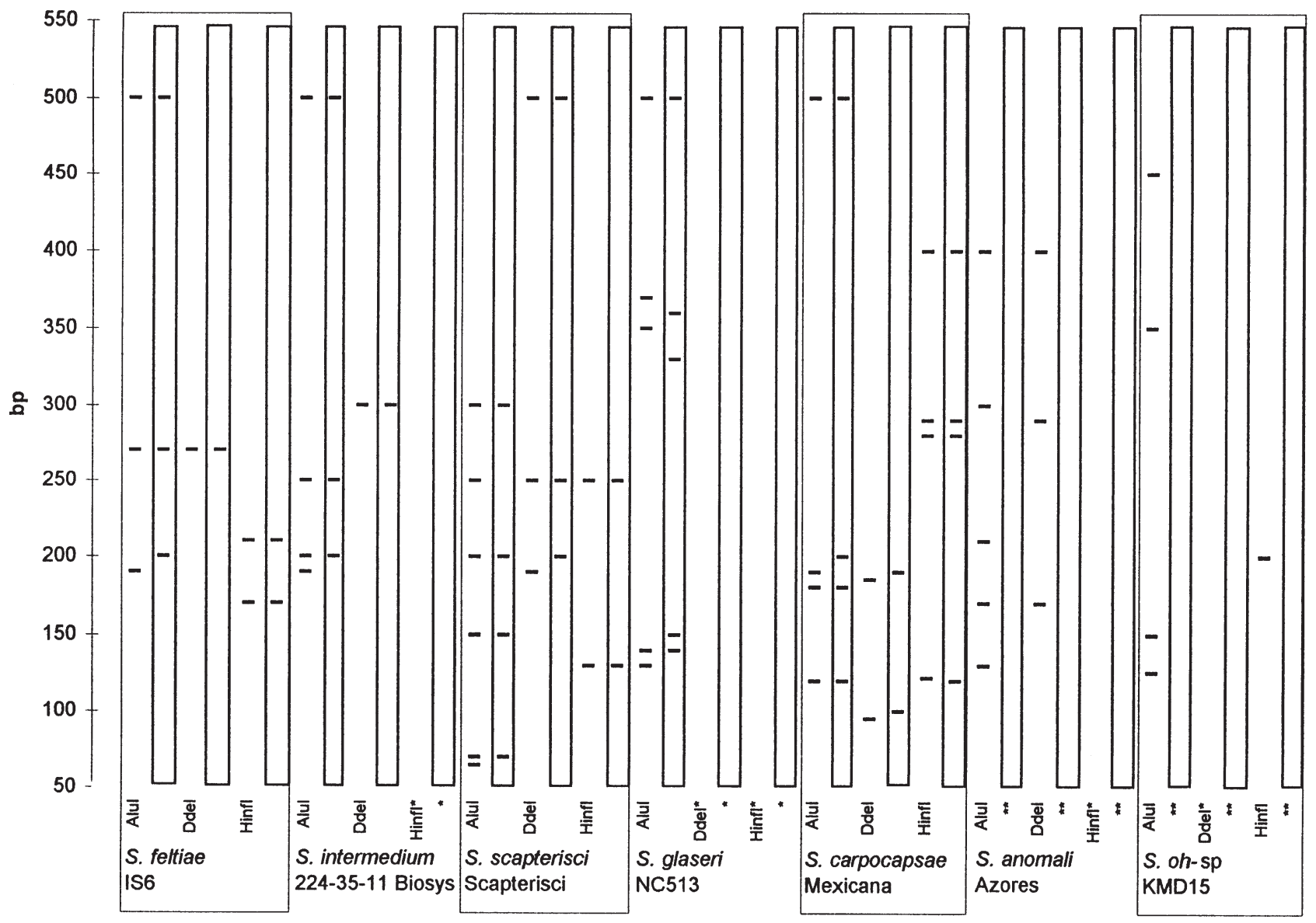

Figure 6. Improved resolution of the PhastSystem RFLP patterns compared to agarose gel electrophoresis patterns of DNA from individuals of strains representing different Steinernema species. RFLP analysis on the PhastSystem using the same conditions as in Fig. 1. Gel electrophoresis patterns on agarose derived from Reid et al. [25]. The patterns derive from digestions with restriction enzymes Alul, Ddel, and Hinfl. The patterns of the KMD15 strain of $S$. oh-sp are distinct from any other Steinernema strain. The 42 gel lanes represent RFLP patterns on acrylamide (odd numbers) and agarose gels (even numbers, boxed lanes); ${ }^{*}$, no restriction fragment in this DNA size range; ${ }^{*}$, no data.

Corresponding results were obtained on the basis of comparisons of the Heterorabditis patterns between PhastSystem and agarose (Reid, A., in preparation) gels. For instance, the comparison of the Alul, Ddel, Hinfl and Rsal restriction patterns of $H$. argentinensis obtained on agarose and PhastSystem gels shows the identity of all corresponding patterns. Considering the advantages and the reproducibility of the results provided by the technique presented here, the use of PhastSystem electrophoresis as an alternative for the molecular identification of EPN strains can be recommended.

This work was supported by the US-Hungarian Joint Fund, Project No. 441-95. The authors express their appreciation and thanks to Dr. Andreas Chrambach (NICHD, NIH, Bethesda, MD, USA) for his invaluable help at different stages of preparing the manuscript and to
József Antal, (Agricultural Biotechnology Center, Gödöllõ, Hungary), for designing and creating Figs. 5 and 6. We express our thanks to the COST Action 819 community for help in obtaining nematode strains and for training our young scientists. We thank in particular Drs. Bill Hominick (CABI International, England), Erko Stackebrandt (DSMZ Braunschweig, Germany), Lonne Gerritsen (IPO-DLO, Wageningen, The Netherlands), Gyula Sáringer (Pannon University of Agricultural Sciences Keszthely, Hungary) as well as Harry Kaya (Department of Nematology, University of California, Davis, CA, USA). We also wish to express our appreciation for the technical assistance of Emese Karácsony (Agricultural Biotechnology Center, Gödöllõ, Hungary), Sára Simon and Piroska Magyar (Eötvös University, Budapest, Hungary).

Received October 23, 1998 


\section{References}

[1] Poinar, Jr., G. O., in: Gaugler, R. and Kaya, H. K. (Eds.), Entomopathogenic Nematodes in Biological Control, CRC Press, Boca Raton 1990, pp. 23-61.

[2] Boemare, N. E., Akhurst, R. J., Mourant, R. G., Int. J. Syst. Bacteriol. 1993, 43, 249-255.

[3] Forst, S., Nealson, K. H., Microbiol. Rev. 1996, 60, 21-43.

[4] Szállás, E., Koch, C., Fodor, A., Burghardt, J., Buss, O., Szentirmai, A., Nealson, K. H., Stackebrandt, E., Int. J. Syst. Bacteriol. 1997, 47, 402-407.

[5] Andrássy, I., in: Andrássy, I. (Ed.), Evolution as a Basis for the Systematization of Nematodes, Akadémiai Kiadó, Budapest 1976, pp. 89-95, 138.

[6] Blaxter, M. L., De Ley, P., Garey, J. R., Liu, L. X., Scheldeman, P., Vierstraete, A., Vanfleteren, J. R., Mackey, L. Y., Dorris, M., Frisse, L. M., Vida, J. T., Thomas, W. K., Nature 1998, 392, 71-75.

[7] Hillis, D. M., Dixon, M. T., Quarterly Rev. Biol. 1991, 66, 411-453.

[8] Dix, I., Griffin, C. T., Joyce, S. A., Burnell, A., Downes, M. J., Nematropica 1996, 26, 256-257.

[9] Powers, T. O., Todd, T. G., Burnell, A. M., Murray, P. C., Flemming, C. C., Szalanski, A. L., Adams, B. J., Harris, T. S., J. Nematol. 1997, 4, 441-450.

[10] Joyce, S. A., Burnell, A. M., Powers, T. O., J. Nematol. 1994, 26, 260-270.

[11] Cherry, T., Szalanski, A. L., Todd, T. C., Powers, T. O., J. Nematol. 1997, 29, 23-29.

[12] Adams, B. J., J. Nematol. 1998, 30, 1-21.

[13] Adams, B. J., Burnell, A. M., Powers, T. O., J. Nematol. 1998, 30, 22-39.

[14] Steiner, G., Zentralbl. Bakteriol. Parasitenkd. Infektionskr. Hyg. Abt. 1923, 2, 59, 14-18.

[15] Steiner, G., J. Wash. Acad. Sci. 1929, 19, 436-440.

[16] Filipjev, I. N., Mag. Parasitol. Inst. Zool. Acad USSR 1934, 4, 229-240.

[17] Weisser, J., Vestn. Cesk. Spol. Zool. 1955, 19, 44-47.

[18] Kozodoi, E. M., Zool. Zhur. 1984, 63, 1605-1609.

[19] Poinar, Jr., G. O., Rev. Nematol. 1985, 8, 321-327.

[20] de Doucet, M. M. A., Rev. Nematol. 1986, 9, 317-320.

[21] Poinar, Jr., G. O., Mracek, Z., Doucet, M. M., Rev. Nematol. 1988, 11, 447-451.

[22] Mamya, Y., Jpn. Appl. Entomol. Zool. 1988, 23, 313-320.

[23] Nishimura, Y., Hagivara, A., Suzuki, t., Yamanaka, S., World J. Microbiol. Biotechnol. 1994, 10, 207-210.

[24] Nguyen, K. G., Smart, Jr., G. C., J. Nematol. 1990, 22, 187-199.
[25] Reid, A. P., Hominick, W. M., Briscoe, B. R., System. Parasitol. 1997, 37, 187-193.

[26] Poinar, Jr., G. O., J. Nematol. 1975, 21, 463-470.

[27] Dix, I., Koltai, H., Glazer, I., Burnell, A., Fundam. Appl. Nematol. 1994, 17, 17-27.

[28] Dix, I., Burnell, A. M., Griffin, C. T., Joyce, S. A., Nugent, M. J., Downes, M. J., Parasitology 1992, 104, 509-518.

[29] Akhurst, R. J., Nematol. 1987, 33, 1-9.

[30] Joyce, S. A., Griffin, C. T., Burnell, A. M., Nematologica 1994, 40, 600-612.

[31] Kahn, A., Brooks, W. W., Hirschmann, H., J. Nematol. 1976, 8, 159-168.

[32] Curran, J., Rev. Nematol. 1989, 12, 145-148.

[33] Curran, J., Webster, J. M., J. Nematol. 1989, 21, 140-145.

[34] Vrain, T. C., Wakarchuk, D. A., Levesque, A. C., Hamilton, R. I., Fundam. Appl. Nematol. 1992, 15, 563-573.

[35] Griffin, C. T., Joyce, S., Dix, I., Burnell, A., Downes, M. J., Fundam. Appl. Nematol. 1994, 17, 245-253.

[36] Gardner, S. L., Stock, S. P., Kaya, H. K., J. Parasitol. 1994, 80, 100-106.

[37] Liu, J., Berry, R. E., J. Invertebr. Pathol. 1996, 67, 48-57.

[38] Nasmith, C. G., Speranzini, D., Jeng, R., Hubbes, M., J. Nematol. 1996, 28, 15-25.

[39] Nguyen, K. G., Smart, Jr., G. C., J. Nematol. 1990, 28, 286-300.

[40] Stock, S. P., Kaya, H. K., Parasitology 1996, 82, 806-813.

[41] Stock, S. P., Strong, D., Gardner, S., Fundam. Appl. Nematol. 1996, 19, 585-592.

[42] Stock, S. P., Nematologica 1997, 43, 455-463.

[43] Poinar, Jr., G. O., Jackson, T., Klein, M., Proc. Helminthol. Soc. Wash. 1987, 54, 53-59.

[44] Wouts, W. M., Nematologica 1979, 25, 191-202.

[45] Smits, P. H., Groenen, J. T. M., De Raay, G., Rev. Nematol. 1991, 14, 445-453.

[46] Glazer, I., Kozodoi, E., Hashmi, G., Gaugler, R., Nematologica 1996, 42, 481-492.

[47] Glazer, I., Gaugler, R., Segal, D., J. Nematol. 1991, 23, 324-333.

[48] Buzás, Z., Wheeler, D. L., Garner, M. M., Tietz, D., Chrambach, A., Electrophoresis 1994, 15, 1028-1031.

[49] Triga, D., Pamjav, H., Vellai, T., Fodor, A., Buzás, Z., Electrophoresis 1999, 20, 1272-1277.

[50] Shapiro, D., Glazer, I., Segal, D., Biol. Control 1997, 8, 153-159.

[51] Griffin, C. T., Dix, I., Joyce, S. A., Burnell, A. M., Downes, M. J., Int. J. Fundam. Appl. Nematol., submitted. 